\title{
P02-12-31 Poster session
}

\section{Ethanolic Extract of Tithonia divrsifolia (Hemsey) A Gray Inhibit Migration Activity and Decrease TGF beta and VEGF expression on Keloid Fibroblast}

\author{
Mae Sri Hartati Wahyuningsih ${ }^{1}$, Dwi Aris Agung Nugrahaningsih ${ }^{1}$, Arief Budiyanto $^{2}$ \\ ${ }^{I}$ PHARMACOLOGY AND THERAPY, FACULTY OF MEDICINE, Indonesia, 22Department of Dermatology, Faculty of
} Medicine, Universitas Gadjah Mada, Indonesia

Background. Keloid occured by abnormal wound healing is characterized by massive fibroblast proliferation and excessive collagen accumulation. Therapy for keloid is relatively limited and has side effects. Tithonia diversifolia Hemsley A Gray has known to have anti proliferative effect against some cancer cells in vitro. However its potential as anti keloid has not ben explored.

Objective. This study aims to assess the T. diversifolia ethanolic extract effect on fibroblast migration activity TGF beta and VEGF expression of keloid fibroblasts in vitro.

Methods. Fibroblast were isolated from keloid collected from patient keloid tissue. The migration activity of keloid fibroblast was assessed using scratch assay. TGF beta and VEGF expression examination were done using ELISA.

Results. Ethanolic extract of T diversifolia treatment at concentration of $20 \mathrm{ug} / \mathrm{mL} 10 \mathrm{ug} / \mathrm{mL}$ and $5 \mathrm{ug} / \mathrm{mL}$ for 24 hour on keloid fibroblast culture showed slower migration activity compare to those on keloid fibroblast culture without treatment $(\mathrm{p}<0.05)$. The TGF beta and VEGF expression were significantly lower in ethanolic extract of $\mathrm{T}$ diversifolia treatment group compare to those on keloid fibroblast without treatment $(p<0.005)$.

Conclusion. Ethanolic extract of $\mathrm{T}$ diversifolia inhibit fibroblast migration activity and decrease the expression of VEGF ang TGF beta on keloid fibroblasts in vitro. 